\title{
COVID-19 pandemic and mitigation strategies: Implications on pig and poultry enterprise in Nigeria
}

${ }^{1}$ Adebiyi, F. G., ${ }^{1}$ Adebiyi, O. A., ${ }^{2}$ Thomas, K. A., ${ }^{3}$ Majekodunmi, B. C. and ${ }^{1}$ Olatunji, G. J. ${ }^{I}$ Department of Animal Science, University of Ibadan, Ibadan, Oyo State, Nigeria

${ }^{2}$ Department of Agricultural Extension and Rural Development, University of Ibadan, Oyo

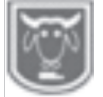

State, Nigeria.

${ }^{3}$ Department of Animal Physiology, Federal University of Agriculture, Abeokuta, Ogun State, Nigeria.

Abstract Corresponding author:fgadebiyi@gmail.com

COVID-19 is a novel disease, which has affected several people across the globe and with a heavy toll on the economy. The impact is yet to be fully quantified in the agricultural sector. In this study, the perceptions of pig and poultry farmers on the effects of the pandemic and coping mechanism during the lockdown period were investigated. A total of 108 farmers participated in this study. Structured questionnaires were administered to pig and poultry farmers (South-West Nigeria) electronically between June and July 2020. Information about knowledge of COVID-19, the effects on livestock enterprise and coping mechanism were obtained. Data were analysed using descriptive analysis. Most of the respondents (98.1\%) had adequate knowledge of the mode of transmission as well as prevention of COVID-19. Majority of the respondents (87.4\%) reported a reduction in their income during the lockdown period probably due to drop in sales (84\% respondents) and livestock production (69.5\% respondents), moderate to high increase in prices of livestock feeds $(66.4 \%$ respondents) and inability to take farm products to market due to movement restriction policy. Most of the farmers $(96.2 \%)$ reported that the government did not render adequate assistance to farmers during the lockdown. However, a few of the farmers (12\%) did not suffer loss of revenue. Some of the farmers (22.4 - $62.5 \%$ respondents) had mild to moderate negative impact of COVID-19 on their farm due to the coping strategies practised during this period. In conclusion, there is need for appropriate intervention of the government and professional bodies during any pandemic to ensure the sustainability of pig and poultry industries.

Keywords: COVID-19, coping strategies, poultry, pigs, farmers

\section{La pandémie COVID-19 et stratégies d'atténuation: Implications sur les entreprises de porcs et de volailles au Nigéria}

\section{Résumé}

Le COVID-19 est une nouvelle maladie, qui a affecté plusieurs personnes à travers le monde et a un lourd tribut pour l'économie. L'impact n'est pas encore pleinement quantifié dans le secteur agricole. Dans cette étude, les perceptions des éleveurs de porcs et de volailles sur les effets de la pandémie et le mécanisme d'adaptation pendant la période de verrouillage ont été étudiées. Au total, 108 agriculteurs ont participé à cette étude. Des questionnaires structurés ont été administrés par voie électronique aux éleveurs de porcs et de volailles (sud-ouest du Nigéria) entre juin et juillet 2020. Des entretiens téléphoniques et en face à face ont également été menés au cours de la même période. Des informations sur la connaissance du COVID-19, les effets sur l'entreprise d'élevage et le mécanisme d'adaptation ont été obtenues. Les données ont été analysées à l'aide d'une analyse descriptive. La plupart des répondants $(98,1 \%)$ avaient une connaissance adéquate du mode de transmission ainsi que de la prévention du COVID-19. La majorité des répondants (87,4\%) ont signalé une 


\section{COVID-19 Pandemic and mitigation strategies: Implications on pig and poultry enterprise}

réduction de leurs revenus pendant la période de verrouillage probablement due à une baisse des ventes ( $84 \%$ des répondants) et de la production animale (69,5\% des répondants), une augmentation modérée à forte des prix des aliments pour bétail (66,4\% répondants) et l'incapacité de mettre les produits agricoles sur le marché en raison de la politique de restriction des mouvements. La plupart des agriculteurs (96,2\%) ont déclaré que le gouvernement n'avait pas fourni une assistance adéquate aux agriculteurs pendant le verrouillage. Cependant, les résultats des entretiens téléphoniques de suivi et des entretiens en face à face ont indiqué que quelques-uns des agriculteurs (12\%) qui utilisaient leurs véhicules pour le marché mobile et utilisaient des plateformes de médias sociaux pour commercialiser leurs produits agricoles ont déclaré une perte de revenus minime. De nombreux agriculteurs ont eu un impact négatif léger à modéré (22,4 à 62,5\% des répondants) du COVID-19 sur leur ferme en raison des stratégies d'adaptation mises en cuvre pendant cette période. En conclusion, une intervention appropriée du gouvernement et des organismes professionnels est nécessaire pendant toute pandémie pour assurer la durabilité des industries du porc et de la volaille.

\section{Mots clés: COVID-19, stratégies d'adaptation, volaille, porcs, agriculteurs}

\section{Introduction}

The global outbreak of COVID-19 pandemic presented many challenges to nations of the earth and its impact had continued to be felt in the life of everyone (Tripathi et al., 2020). Pandemics have occurred throughout history and seem to be increasing in frequency, particularly because of the increasing emergence of viral disease from animals (Madhav et al.et al., 2017). From past pandemics that the world has experienced, it has been shown that quarantines and panic have impacts on farmers' activities and economic growth (Bermejo, 2004; Hanashima and Tomobe, 2012). Lessons from past epidemics indicate that disruptions in the activities of farmers are likely to have dire socioeconomic consequences. The index case of coronavirus in Nigeria was recorded on 27 February 2020 in Lagos and the number of confirmed cases had risen to over 60,000 people. With an increasing number of COVID-19 cases in March 2020, states in Nigeria ordered either a partial or total lockdown according to the severity of COVID-19 in each area. There was also an interstate restriction of movement. The mobility restrictions and the reduced purchasing power negatively impacted the agricultural sector (Siche, 2020). Current observations revealed that there were disruptions to value chains in various agricultural sectors during the lockdown (FAO, 2020). Many poultry and swine farmers have recorded great losses during this period (FAO, 2020). An increasing number of on-farm problems have been witnessed in various countries as a result of COVID-19 (Stephens et al., 2020). Many livestock farmers in developing and developed countries suffered not only from income loss due to overstocked products but also from a shortage of vital farm inputs. For example, in Nigeria, many hatcheries could not deliver day-old-chicks to farms. Many of the livestock farmers also experienced a hike in the price of feed due to decrease in the supply of livestock feeds which were occasioned by government policy of movement restriction. Many of the poultry farmers also experienced egg gluts which resulted in more than a 50\% decrease in the price of eggs. Furthermore, several crates of eggs were smashed and discarded to create space for storage of freshly laid eggs during the lockdown (Yahaya et al., 2020). In developed countries such as the United States, Canada and China, overstocked 


\section{Adebiyi, Adebiyi, Thomas, Majekodunmi nd Olatunji}

milk, vegetables, livestock, and poultry were dumped or destroyed (Qingbin et al., 2020; Weersink et al., 2020; Yaffe-Bellany and Corkery, 2020). Given the disruptions in the livestock sector occasioned by the COVID-19 pandemic, there is a need to quantify the effect of this pandemic on poultry and pig enterprise and devise a sustainable coping mechanism for poultry and pig farmers in other to ensure food security even in the heat of any subsequent pandemic. Therefore, this study was designed to assess the effects of the COVID-19 pandemic on poultry and pig farming enterprise and identify the various coping mechanisms explored by the farmers during the period of COVID-19 lockdown.

\section{Methodology}

The study was conducted in Nigeria during the COVID-19 pandemic. A total of 108 farmers participated in this study which represented farmers with low and highdensity flock sizes. Structured Questionnaires were sent to swine and poultry farmers (South-West of Nigeria) electronically using Google survey form between June and July 2020. Telephone calls and phone interviews were used as means of following up with farmers to ensure that the electronic questionnaire was duly filled. Few of the farmers with low proficiency in filling an online survey were provided with hard copies of the questionnaires while maintaining adequate COVID-19 protocol. A convenient sampling method was used to administer both hard copy and electronic questionnaires. A purposive sampling technique was used to select respondents who had over ten years of experience for the telephone and face-to-face interviews. Data were collected on demographic characteristics and general information of farm experience, Knowledge of COVID19, effects of COVID-19 pandemic on livestock enterprise and coping mechanism of pig and poultry farmers during the period of COVID-19 lockdown. The severity of COVID-19 on livestock business was assessed on a four Likert-type scales (i.e low, moderate, high and not applicable). Respondents reflected their coping strategies to cushion the effect of COVID19 lockdown on the sales and welfare of their livestock. The perceptions of farmers on the roles of the Animal Science Association of Nigeria (ASAN) and Nigeria Institute of Animal Science (NIAS) in ameliorating the effect of COVID-19 lockdown on pigs and poultry enterprise were investigated using a five Likert-type scales, which ranged from strongly agree to strongly disagree. The data were analysed using descriptive analysis.

\section{Results \\ Demographic characteristics of respondents}

Table I shows the distribution of respondents according to their demographic characteristics. The highest age range of the respondents was between 50 and 59 years and a greater proportion of the farmers were males $(62.5 \%)$. The majority $(97.1 \%)$ of the respondents were educated to the tertiary level. Table 2 shows the percentage distribution of type of livestock, ownership status as well as years of experience in livestock enterprises. The majority of the respondents had over 5-year experience in the poultry/piggery enterprise. Figures 1 and 11 indicate the size of each livestock farm. A large number of the respondents $(31.5 \%)$ reared more than 100 pigs. Quite a large number of farmers $(31.7 \%)$ also raised more than 500 layers and or broilers. 


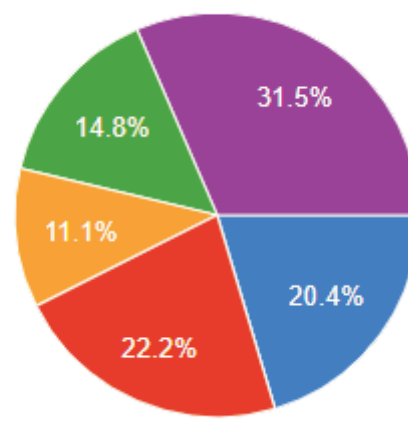

Figure 1: Stock size for pigs

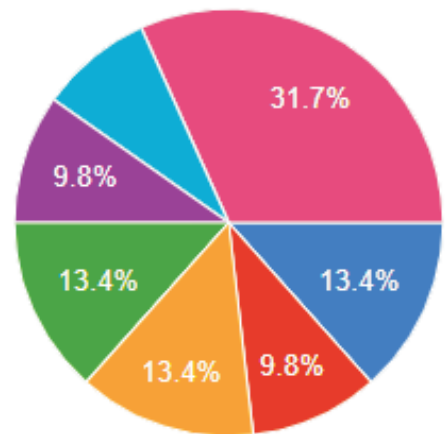

Figure II: Stock size for poultry

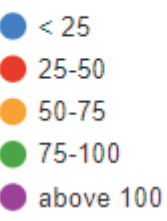

above 100

$<<50$

$50-100$

$100-200$

$200-300$

$300-400$

$400-500$

above 500

\section{Knowledge of COVID-19}

Respondents' awareness of COVID-19 is shown in Table 3 and Figure III. The majority of the respondents $(96.2 \%)$ believed that it was caused by a virus. Most of the respondents had adequate knowledge of COVID-19 and understood the mode of transmission of the disease as well as its prevention. About $98.1 \%$ of the respondents believed that COVID-19 could be transmitted through respiratory droplets of an infected individual and that asymptomatic people could transmit the virus. However, $31.4 \%$ of the respondents indicated that COVID-19 could also be contracted from livestock while $68.6 \%$ opined that COVID-19 cannot be contracted from livestock. A high proportion of the respondents received information on risks and prevention of COVID-19 through social media $(90.5 \%)$, television $(87.6 \%)$ and radio $(77.1 \%)$ stations (Figure IV). 


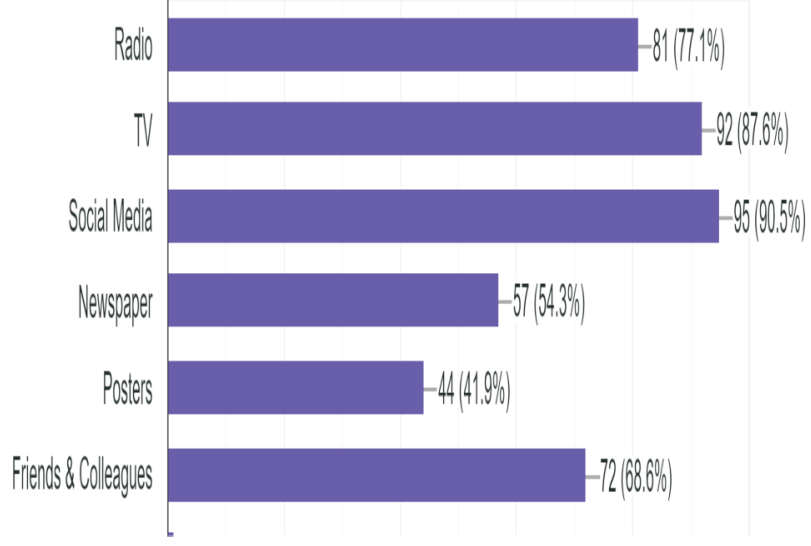

Figure III: Medium of awareness of COVID-19

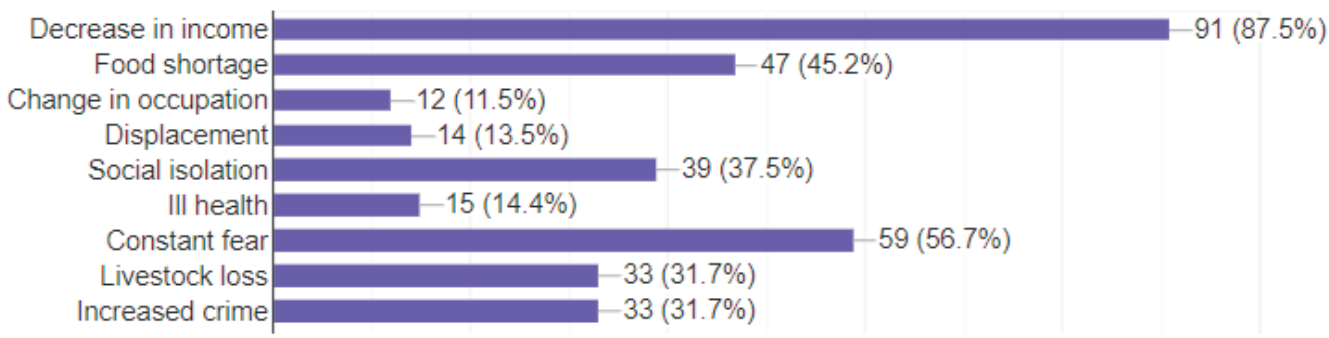

Figure IV: Effect of COVID-19 on the welfare of pigs and poultry farmers

Table 1: Distribution of respondent according to their demographic characteristics

\begin{tabular}{|c|c|c|c|c|}
\hline Variables & Category & Frequency & Percer & \\
\hline Age & $<20$ & 2 & 1.9 & \\
\hline & $20-29$ & 11 & 10.7 & \\
\hline & $30-39$ & 22 & 21.4 & \\
\hline & $40-49$ & 27 & 26.2 & \\
\hline & $50-59$ & 29 & 28.2 & \\
\hline & $60-69$ & 12 & 11.6 & \\
\hline & $>70$ & 0 & & \\
\hline Mean Age & & & 44.9 & \\
\hline Sex & Male & 65 & 62.5 & \\
\hline & Female & 39 & 37.5 & \\
\hline Education Status & Primary education & 0 & 0 & \\
\hline & Secondary education & 3 & 2.9 & \\
\hline & Tertiary education & 102 & 97.1 & \\
\hline able 2. Livestec & rise & & & \\
\hline & able & Group & Frequency & Percentage \\
\hline Type of livestock & & Poultry & 78 & 72.2 \\
\hline & & Piggery & 39 & 36.1 \\
\hline & & other & 13 & 12.0 \\
\hline Livestock enterpr & ership status & $\begin{array}{l}\text { Personally } \\
\text { owned }\end{array}$ & 83 & 79.8 \\
\hline & & Employee & 13 & 12.5 \\
\hline & & Leased/rent & 8 & 7.7 \\
\hline Years of experien & vestock enterprise & $<1 \mathrm{yr}$ & 0 & 0 \\
\hline & & $1-<5 y$ rs & 35 & 36.5 \\
\hline & & $5-<10$ yrs & 26 & 27.0 \\
\hline & & above $10 y r s$ & 35 & 36.45 \\
\hline Major customer & & Wholesale & 47 & 43.5 \\
\hline & & Individuals & 68 & 63.0 \\
\hline & & Government & 1 & 0.9 \\
\hline
\end{tabular}


COVID-19 Pandemic and mitigation strategies: Implications on pig and poultry enterprise

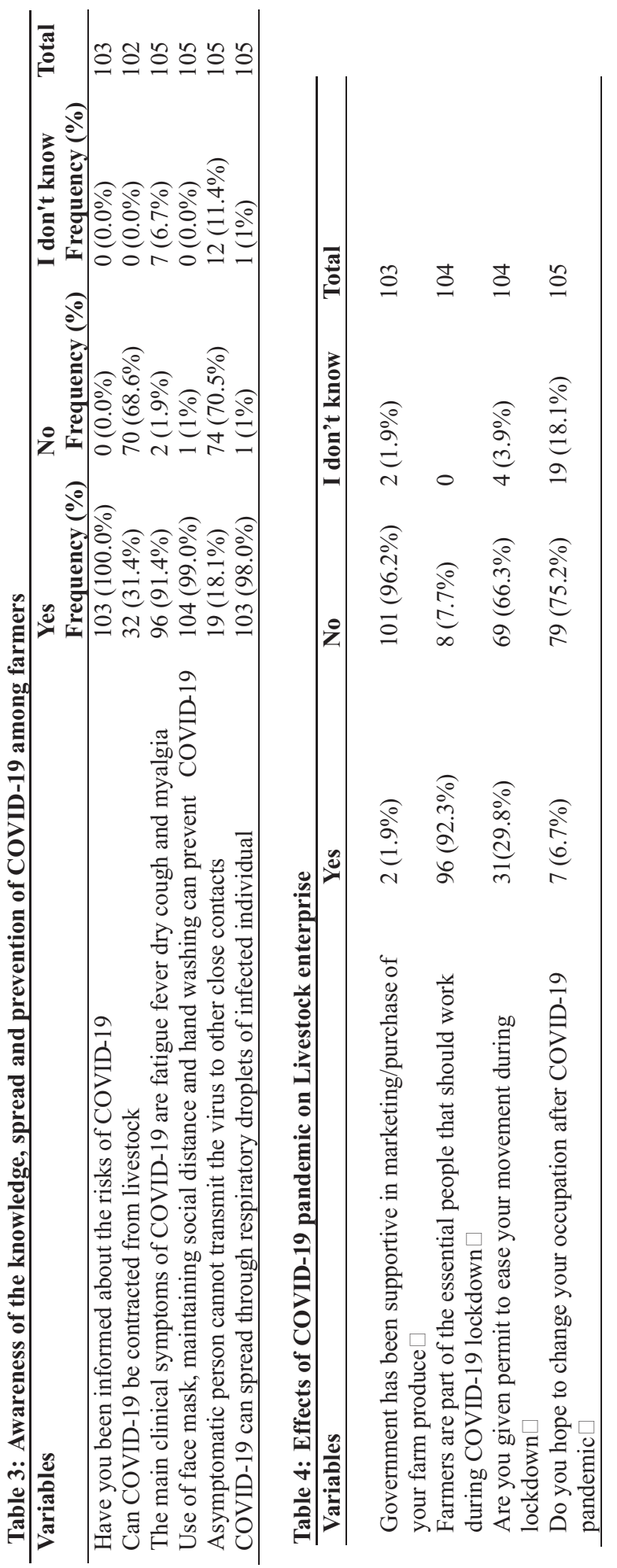




\section{Adebiyi, Adebiyi, Thomas, Majekodunmi nd Olatunji}

Effects of COVID-19 pandemic on livestock enterprise

The effects of COVID-19 on Livestock enterprise is shown in Table 4, Figures IV, V and VI. Farmers (69.5\%) documented a decrease in production during the lockdown. Majority of the respondents (84\%) experienced a decrease in sales of farm products. A vast number of respondents $(87.5 \%)$ experienced a decrease in income and constant fear. Many of the farmers $(49 \%)$ were stopped by security agents on the way to their farms during the lockdown though $71.2 \%$ of the respondents went to farms in their vehicles while others who lived close to farms trekked. About $66.3 \%$ of the respondents did not get a permit to move around especially to their farms during the lockdown. Also, face-to-face interview of some selected farmers revealed that some of the farmers were kidnapped for a ransom during the lockdown. Table 5 shows the level of severity of the COVID-19 pandemic/lockdown on the livestock enterprise. Majority of the pig farmer respondents at Okearo, Ogun state, southwest, Nigeria reported that they lost their animals to Africa Swine Fever which occurred during the lockdown.

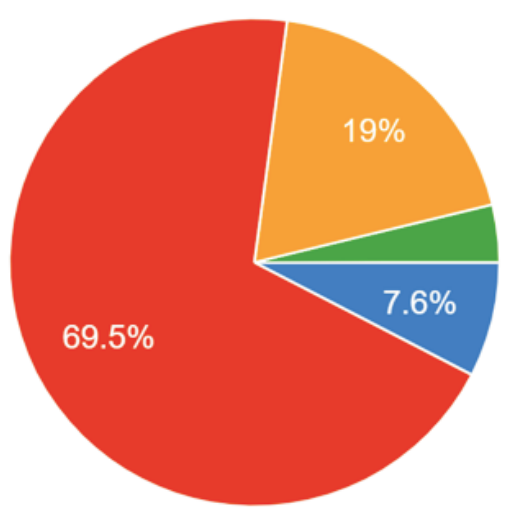

Increase

Decrease

About the same

I don't know

Figure V: Effect of COVID-19 on livestock production

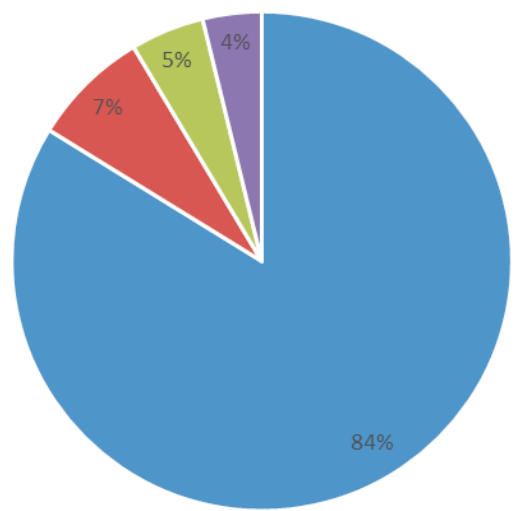

- Decrease

- About the same

- Increase

- I don't know

Figure VI: Effect of COVID-19 on sales of pigs and poultry products 
COVID-19 Pandemic and mitigation strategies: Implications on pig and poultry enterprise

Table 5: Severity of COVID-19 pandemic on livestock enterprise

\begin{tabular}{|c|c|c|c|c|c|}
\hline \multirow[t]{2}{*}{ Description of shortfall } & \multicolumn{3}{|c|}{ Severity } & \multirow{2}{*}{$\begin{array}{l}\text { Not } \\
\text { applicable } \\
(\%)\end{array}$} & \multirow[t]{2}{*}{ Total } \\
\hline & Low (\%) & $\begin{array}{l}\text { Moderate } \\
(\%)\end{array}$ & High (\%) & & \\
\hline $\begin{array}{l}\text { I couldn't work on the farm } \\
\text { due to COVID-19 } \\
\text { lockdown }\end{array}$ & $28(26.7 \%)$ & $20(19.0 \%)$ & $2(1.9 \%)$ & $55(52.4 \%)$ & 105 \\
\hline $\begin{array}{l}\text { I experienced major } \\
\text { livestock loss (theft, } \\
\text { disease etc.) }\end{array}$ & $35(33.7 \%)$ & $30(28.8 \%)$ & $9(8.7 \%)$ & $30(28.8 \%)$ & 104 \\
\hline $\begin{array}{l}\text { I experienced other major } \\
\text { asset loss (fire, theft, flood, } \\
\text { etc.) }\end{array}$ & $25(24.0 \%)$ & $9(8.7 \%)$ & $3(2.9 \%)$ & $67(64.4 \%)$ & 104 \\
\hline $\begin{array}{l}\text { I experienced Loss of } \\
\text { employment }\end{array}$ & $21(20.2 \%)$ & $15(14.4 \%)$ & $7(6.7 \%)$ & $61(58.7)$ & 104 \\
\hline I experience egg glut & $10(10.2 \%)$ & $12(12.2 \%)$ & $27(27.6 \%)$ & $49(50.0 \%)$ & 98 \\
\hline $\begin{array}{l}\text { I experienced loss of } \\
\text { livestock due to production } \\
\text { but no sales }\end{array}$ & $26(25.0 \%)$ & $20(19.2 \%)$ & $17(16.3 \%)$ & $41(39.4 \%)$ & 104 \\
\hline $\begin{array}{l}\text { I experienced increase in } \\
\text { price of livestock feed }\end{array}$ & $23(22.1 \%)$ & $34(32.7 \%)$ & $35(33.7 \%)$ & $12(11.5 \%)$ & 104 \\
\hline
\end{tabular}

Table 6: Coping mechanism of piggery and poultry farmers during the period of covid-19 lockdown

\begin{tabular}{|c|c|c|c|c|}
\hline Coping strategies & $\begin{array}{l}\text { Always } \\
(\%)\end{array}$ & $\begin{array}{l}\text { Sometimes } \\
(\%)\end{array}$ & $\begin{array}{l}\text { Never } \\
(\%)\end{array}$ & Total \\
\hline $\begin{array}{l}\text { I reduce price of farm produce to } \\
\text { encourage sales }\end{array}$ & $31(30.1 \%)$ & $57(55.3 \%)$ & $15(14.6 \%)$ & 103 \\
\hline $\begin{array}{l}\text { I have social network that put me in a } \\
\text { vantage position for adequate } \\
\text { marketing of my farm produce during } \\
\text { COVID-19 lockdown }\end{array}$ & $14(13.6 \%)$ & $57(55.3 \%)$ & $32(31.1 \%)$ & 103 \\
\hline $\begin{array}{l}\text { I use my personal vehicle as a mobile } \\
\text { market for sales of farm produce. }\end{array}$ & $24(23.3 \%)$ & $45(43.7 \%)$ & $34(33.0 \%)$ & 103 \\
\hline $\begin{array}{l}\text { I have value chain approaches that } \\
\text { promote home preservation of pork and } \\
\text { poultry products for Post COVID-19 } \\
\text { pandemic. }\end{array}$ & $8(8.1 \%)$ & $40(40.4 \%)$ & $51(51.5 \%)$ & 99 \\
\hline $\begin{array}{l}\text { I adopted several home preservation } \\
\text { methods of pork and poultry products } \\
\text { during COVID-19 lockdown. }\end{array}$ & $15(14.9 \%)$ & $38(37.6 \%)$ & $48(47.5 \%)$ & 101 \\
\hline $\begin{array}{l}\text { I have livestock insurance policy in } \\
\text { order to cushion negative effect of the } \\
\text { pandemic/natural disaster }\end{array}$ & $7(6.9 \%)$ & $13(12.7 \%)$ & $82(80.4 \%)$ & 102 \\
\hline $\begin{array}{l}\text { I increased incentives for Farmworkers } \\
\text { during the lockdown. }\end{array}$ & $22(21.6 \%)$ & $56(54.9 \%)$ & $24(23.5 \%)$ & 102 \\
\hline
\end{tabular}


Adebiyi, Adebiyi, Thomas, Majekodunmi nd Olatunji

Table 7: The role of professional bodies in ameliorating the effect of COVID-19

\begin{tabular}{|c|c|c|c|c|c|c|}
\hline Items & $\begin{array}{l}\text { Strongly } \\
\text { agree }\end{array}$ & Agree & Undecided & Disagree & $\begin{array}{l}\text { Strongly } \\
\text { disagree }\end{array}$ & Total \\
\hline $\begin{array}{l}\text { Initiate widespread } \\
\text { public / risk } \\
\text { communication } \\
\text { campaigns on the } \\
\text { consequences of } \\
\text { hoarding livestock } \\
\text { produce }\end{array}$ & $\begin{array}{l}41 \\
(40.2 \%)\end{array}$ & $\begin{array}{l}42 \\
(41.2 \%)\end{array}$ & $12(11.8 \%)$ & $7(6.8 \%)$ & $0(0 \%)$ & 102 \\
\hline $\begin{array}{l}\text { Initiate policy for } \\
\text { purchase limitations on } \\
\text { specific products during } \\
\text { lockdown }\end{array}$ & $\begin{array}{l}15 \\
(14.9 \%)\end{array}$ & $45(44.6 \%)$ & $19(18.8 \%)$ & $4(3.9 \%)$ & $\begin{array}{l}18 \\
(17.8 \%)\end{array}$ & 101 \\
\hline $\begin{array}{l}\text { Mediate and facilitate } \\
\text { low-cost credit facilities } \\
\text { for small scale piggery } \\
\text { and poultry farmers }\end{array}$ & $\begin{array}{l}66 \\
(63.5 \%)\end{array}$ & $\begin{array}{l}34 \\
(32.7 \%)\end{array}$ & $3(2.9 \%)$ & $1(0.9)$ & $0(0.0 \%)$ & 104 \\
\hline $\begin{array}{l}\text { Organize fair price } \\
\text { markets for farm } \\
\text { produce in urban and } \\
\text { rural areas during the } \\
\text { lockdown }\end{array}$ & $\begin{array}{l}53 \\
(51.0 \%)\end{array}$ & $\begin{array}{l}47 \\
(45.2 \%)\end{array}$ & $3(2.9 \%)$ & $0(0.0 \%)$ & $1(0.9 \%)$ & 104 \\
\hline $\begin{array}{l}\text { Negotiate short-term } \\
\text { debt relief programs (to } \\
\text { preserve assets and cash } \\
\text { reserves) for pig and } \\
\text { poultry farmers }\end{array}$ & $\begin{array}{l}51 \\
(50.5 \%)\end{array}$ & $\begin{array}{l}40 \\
(39.6 \%)\end{array}$ & $6(5.9 \%)$ & $3(3.0 \%)$ & $1(1.0 \%)$ & 101 \\
\hline $\begin{array}{l}\text { Take an inventory of } \\
\text { public and private } \\
\text { storage facilities that } \\
\text { could be used for } \\
\text { emergency food } \\
\text { stockpiling }\end{array}$ & $\begin{array}{l}44 \\
(43.1 \%)\end{array}$ & $\begin{array}{l}44 \\
(43.1 \%)\end{array}$ & $14(13.7 \%)$ & $0(0.0 \%)$ & $0(0.0 \%)$ & 102 \\
\hline $\begin{array}{l}\text { Professional bodies } \\
\text { should be an off-taker of } \\
\text { produce from their } \\
\text { members for easy } \\
\text { marketing }\end{array}$ & $\begin{array}{l}45 \\
(43.7 \%)\end{array}$ & $\begin{array}{l}44 \\
(42.7 \%)\end{array}$ & $6(5.8 \%)$ & $6(5.8 \%)$ & $2(1.9 \%)$ & 103 \\
\hline
\end{tabular}

\section{Coping mechanism of piggery and} poultry farmers during the period of COVID-19 lockdown

Table 6 presents the coping strategies of the respondents during the period of COVID19 Lockdown. Only $30.1 \%$ of the respondents reduced the price of their farm produce. A high proportion of the farmers (approximately 70\%) always and or sometimes adopted social medial/network to market their products, increased incentives for farm workers during the lockdown and about $67 \%$ of the respondents always or sometimes used personal vehicle as a mobile market for sales of farm produce The role of professional bodies in ameliorating the effect of COVID-19 Table 7 presents the perspectives of farmers as to what the role of the Animal Science Association of Nigeria (ASAN) and or 
Nigeria Institute of Animal Science (NIAS) should be in ameliorating the impact of COVID-19 lockdown on pigs and poultry farmers. A high proportion of the farmer respondents $(>80 \%)$ agreed that the professional body should play a supportive role that would alleviate the effect of COVID-19 lockdown on pigs and poultry farmers.

\section{Discussion}

Majority of the farmers in this study were less than 50 years. The mean age of the farmers was approximately 45 years, implying that the farmers were still in their productive age and agile to carry out farming business. The high record of respondents $(97.1 \%)$ with tertiary education is an indication that many university graduates are now involved in the poultry and piggery business in Nigeria. The high literacy level of the farmers may have a positive impact on the stability of their business in that, most of the respondents $(63.5 \%)$ had over 5years of experience in livestock enterprise. The formal education may enhance acquired practical knowledge for efficient routine management, hence, increase productivity of livestock and sustainability of the pig and poultry business (Oduro-Ofori et al., 2014). The social media, television and radio stations were the most effective way through which respondents received information on risks and prevention of COVID-19. This is probably because more people spent more time on social media, radio and television during the lockdown. Therefore, people could easily get information through these media. It has been reported by Chan et al. (2020) that social media has the potential if responsibly and appropriately used, to provide rapid and effective dissemination routes for key information on the COVID19 pandemic. Majority of the farmers experienced a decrease in income as a result of decrease in production and sales of livestock produce. This could be associated with the movement restriction policy which prevented farm customers to have access to farm produce during the lockdown. FAO (2020) also reported that movement restrictions and illness resulted in labour shortages and reduced supply of raw materials or other feed ingredients during the lockdown in many countries. Furthermore, the majority of the farmer respondents reported decreased in price and sales of livestock products during the period, this might have accounted for the record of decrease in income of the respondents $(87.5 \%)$. The decrease in sales of pig and poultry products observed could also be a result of the closure of some animal markets/major markets and movement restrictions. Also, disruption of the distribution channel might have caused the drop in demand and reduction of prices of pigs, day-old chicks and poultry products. The same situation has been observed in many countries affected by COVID-19, For example, American pig prices dropped by roughly $27 \%$ during the lockdown (FAO, 2020). The decrease in income could also be associated with the record of low interest of the government in the market chain as most of the respondents stated that the government had not been supportive in the marketing and purchasing of farm produce. Furthermore, the reduction in income could be related to the attitude of farmers to livestock insurance policy. Most of the farmers under study do not have a livestock insurance policy that could cushion the negative impact of the COVID-19 pandemic on farm business. However, the role of the government and Agricultural insurance companies in the sustainability of livestock enterprise is very crucial at this time. The Canadian government, in connection with agro-insurance companies, was able to provide relief for livestock producer facing COVID-19 challenges and thereby sustain the income of the farmers (Agroinsurance, 2020). Many respondents 


\section{Adebiyi, Adebiyi, Thomas, Majekodunmi nd Olatunji}

experienced loss of livestock due to production but no sales. The loss of livestock, especially pigs, day-old chicks and broilers might have been a result of limited access of farmers to markets and slaughterhouses. Also, many of the farmers kept their stock longer leaving them with higher production costs or vital losses. The Pig Progress webpage reported that several leading pig farmers in various continents, though, continued their operations during the lockdown but the biggest bottleneck observed was that the processors were finding it difficult to get the pigs to consumers. This effect also trickled through and affected the pig producers indirectly (Pig Progress, 2020). The poultry farmers who experienced severity of egg glut were about $27.6 \%$ most of which were farmers with above 500 stock sizes despite some of them used their personal vehicles as a mobile market for sales of eggs. This may be an indication that the impact of COVID19 was felt more by farmers with high stock density. Another challenge to pig and poultry farmers during the COVID-19 lockdown was an increase in the price of feed and feed shortage. This may be attributed to delay in getting feed across to farmers from the feed suppliers due to interstate restriction of movement. The same observation was also reported by FAO, (2020) that disruption of supply routes might cause further delayed of feed supply to many farmers which may result in feed shortage. Some of the respondents were able to cope with the adverse effect of the COVID-19 lockdown because they reduced the price of their farm produce to encourage sales, used social networking to market their products and their car as a mobile market for sales of farm produce. The $13.6 \%$ of the respondents who used the social network to market their farm produce during the locked recorded little or no reduction in the sales of farm produce. From the telephone interview, $14.6 \%$ of the respondents who did not reduce the price of their products were involved in active online platform marketing and use of the personal vehicle as a mobile market to supply their products to people who booked through various social media platforms. These farmers were able to establish a wellorganised marketing strategy through social media. This is an indication that social media/social networking could be a powerful avenue for sales of goods and services. This finding concurred with Meeme (2020) who started that adoption of social media in the marketing of agricultural products during the COVID-19 pandemic increased efficiency in marketing of farm produce and hence enhanced the turnover. Also, social media has been seen as an effective mechanism that contributes to the firms' marketing aims and strategy, especially in the aspects related to customers' involvement (Filo et al., 2015; Alalwan et al., 2017). It was also noted that many of the farmers adjusted their production plans by downsizing their production. For example, most of the piggery farmers stopped mating their sows and the broiler farmers refused to take in day-old chicks. A large number of respondents also encouraged their farmworkers to come to work by giving incentives. This became imperative during the lockdown because incentives are often considered a major factor in the ability to retain worker (Falola et al., 2014). This singular act must have contributed to the low record of loss of employment in this study.

Another coping mechanism reported by a relatively high number of farmers in this study was the value chain approaches that could promote home preservation of pork and poultry products during the lockdown. This coping strategy might have accounted for the relatively large number of farmers who stated that they do not hope to change their occupation after COVID-19 
pandemic. This is also an indication that most of the farmers in this study were able to devise a suitable coping mechanism which relatively favoured their business. The farmers' high level of education, many years of experience as well as acquisition of practical knowledge in routine farm management must have accounted for the high response observed. The roles of the animal production regulatory bodies [Animal Science Association of Nigeria (ASAN) and/or Nigeria Institute of Animal Science (NIAS)] were assessed in this study. A greater proportion of the respondents (81.4\%) agreed that the animal production regulatory bodies should initiate widespread public/risk communication campaigns on the consequences of hoarding livestock produce during the COVID-19 pandemic. This is particularly needed in the animal feed and feed ingredient industry in which most of the farmers experienced an increase in the price of feed due to high demand and low supply of animal feed. Since most of the respondents experienced low sales of their products and subsequently low income during the COVID-19 pandemic/lockdown, majority of the farmers opined that Professional bodies should help to market the farm produce by organizing fair price markets in urban and rural areas during the lockdown and initiate policy for purchase limitations on specific products during the lockdown. A vast majority of pig and poultry farmers would have benefited greatly if these professional bodies had carried out these roles. Majority of the farmers $(82.4 \%)$ in this study also agreed that the professional bodies for animal production in Nigeria should provide transportation support that allows producers to get their products to market. This would probably have reduced the interception by policemen experienced by some of the respondents on their way to either farm or market. The vast majority of pig and poultry farmers $(86.1 \%)$ agreed that the professional bodies should mediate and facilitate low-cost credit facilities for small scale piggery and poultry farmers which could help boost the business of farmers during and after the lockdown.

\section{Conclusion}

The income of many farmers under study reduced due to drop in sales of pigs and poultry products and livestock production, increase in price of feed and inability to take their products to the market. However, some of the poultry and pig farmers who used their vehicles as mobile market and utilised social media provided a good platform for products marketing. Though the government and professional bodies seemed not to provide adequate relief to farmers facing COVID-19 challenges, most of the farmers developed several coping strategies to ease the effect of the pandemic. It is therefore imperative for the government to enact a law that will enable farmers to have free access to their farm during any lockdown, give adequate support and encourage farmers to have an appropriate insurance policy for their farm business.

\section{References}

Adam, V. Y., Qasim, A. M. and Kazeem, M. O. 2014. Assessment of the Knowledge of Poultry Farmers and Live Poultry Sellers to Preventive and Control Measures on Bird Flu, Benin City, Nigeria. Epidemiology Research International, Vol 2014, Article ID 651619, 6 pages. https://doi.org/10.1155/2014/6516 19

Agroinsurance. 2020. Canada-Relief for livestock producers facing COVID19 challenges [Portal on Agricultural Insurance and Risk Management]. Available online at: https://agroinsurance.com/en/cana da-relief-for-livestock-producersfacing-covid-19-challenges/ 
Alalwan, A. A., Rana, N. P., Dwivedi, Y. K. and Algharabat, R. 2017. Social media in marketing: A review and analysis of the existing literature. Telematics and Informatics, 34 (7), 1177-1190. https://doi.org/10.1016/j.tele.2017. 05.008

Arndt, C., and Lewis, J. D. 2001. The HIV/AIDS pandemic in South Africa: Sectoral impacts and unemployment. Journal of International Development, 13(4), $\begin{array}{lllllll}4 & 2 & 7 & - & 4 & 4 & 9\end{array}$. https://doi.org/10.1002/jid.796

Bermejo, A. 2004. HIV/AIDS in Africa: International responses to the pandemic. New Economy, 11(3), $\begin{array}{llllllll}1 & 6 & 4 & - & 1 & 6 & 9\end{array}$. https://doi.org/10.1111/j.14680041.2004.00357.x

Chan, A. K. M., Nickson, C. P., Rudolph, J. W., Lee, A., and Joynt, G. M. 2020. Social media for rapid knowledge dissemination: Early experience from the COVID 19 pandemic. Anaesthesia.Vol.75(12), $\begin{array}{lllllllll}1 & 5 & 7 & 9 & - & 1 & 5 & 8 & 2\end{array}$ https://doi.org/10.1111/anae.15057

FAO. 2020. Mitigating the impacts of COVID-19 on the livestock sector. Available online at: https://doi.org/10.4060/ca8799en

Filo, K., Lock, D. and Karg, A. 2015. Sport and social media research: A review. Sport Management Review, 18 ( 2), $166-181$. https://doi.org/10.1016/j.smr.2014. 11.001

Hanashima, M., and Tomobe, K. 2012. Urbanization, industrialization, and mortality in modern Japan: A spatio-temporal perspective. Annals of GIS, 18(1), 57-70. https://doi.org/10.1080/19475683. 2011.647078

Madhav, N., Oppenheim, B., Gallivan,
M., Mulembakani, P., Rubin, E., and Wolfe, N. 2017. Pandemics: Risks, Impacts, and Mitigation. In D. T. Jamison, H. Gelband, S. Horton, P. Jha, R. Laxminarayan, C. N. Mock, and R. Nugent (Eds.), Disease Control Priorities: Improving Health and Reducing Poverty (3rd ed.). The International Bank for Reconstruction and Development / The World Bank. http://www.ncbi.nlm.nih.gov/book s/NBK525302/

Meeme, V. 2020. Kenyan farmers take new approach to sales during COVID19 lockdown. Alliance for Science page. Available online at: https://allianceforscience.cornell.e $\underline{\mathrm{du} / \mathrm{blog} / 2020 / 04 / \text { kenyan-farmers- }}$ take-new-approach-to-salesduring-covid-19-lockdown

Oduro-Ofori, E., Aboagye, A. P., and Acquaye, N. A. E. 2014. Effects of Education on the Agricultural Productivity of Farmers in the Offinso Municipality. International Journal of Development Research, 4(9), 1951-1960.

Ologbon, O. A. C., and Ambali, O. I. 2012. Poultry enterprise combination among small scale farmers in Ogun state, Nigeria: A technical efficiency approach. Journal of Agriculture and Veterinary Sc i e nces. 4. 7 - 15 . https://www.cenresinjournals.com/ 2020/02/27/poultry-enterprisecombination-among-small-scalefarmers-in-ogun-state-nigeria-atechnical-efficiency-approach/

Pig Progress. 2020. How are pig producers around the world affected by Covid19? [World of pigs]. Available o $\mathrm{n} 1 \mathrm{i} \mathrm{n} \mathrm{e} \mathrm{a} \mathrm{t}$ : https:/www.pigprogress.net/Worl d-of-Pigs 1/Articles/2020/4/Howare-pig-producers-around-the- 
COVID-19 Pandemic and mitigation strategies: Implications on pig and poultry enterprise

world-affected-by-Covid-19$568258 \mathrm{E} /$

Pu, M., and Zhong, Y. 2020. Rising concerns over agricultural production as COVID-19 spreads: Lessons from China. Global Food Security, 26, 100409 . https://doi.org/10.1016/j.gfs.2020. 100409

Qingbin, W, Liu, C.-Q., Zhao, Y.-F., Kitsos, A., Cannella, M., Wang. S.-K., Han, L. 2020. Impacts of the COVID-19 pandemic on the dairy industry: Lessons from China and the United States and policy implications. Journal of Integrative Agriculture, 19(12), 7-15.

Saxena, A., and Khanna, U. 2013. Advertising on Social Network Sites: A Structural Equation Modelling Approach. Vision: The Journal of Business Perspective 17 ( 1 ), $17-25$. https://doi.org/10.1177/097 2262912469560

Siche, R. 2020. What is the impact of COVID-19 disease on agriculture $\square$ Scientia Agropecuaria, 11(1), 3-6. https://doi.org/10.17268/sci.agrope cu. 2020.01 .00

Stephens, E., Martin, G., Van Wijk, M., Timsina, J., and Snow, V. 2020. Editorial: Impacts of COVID-19 on agricultural and food systems worldwide and on progress to the sustainable development goals. Agricultural Systems, 183, 102873. https://doi.org/10.1016/j.agsy.2020 .102873

Tripathi, D., Sindher, M., and Garg, T. 2020. The Aftermath of Pandemic COVID-19 on Food and Agrisector. Food and Agriculture Spectrum Journal,1(2), 1-11. www.foodagrispectrum.org

UN 2020). Policy Brief: The Impact of COVID-19 on Food Security and
Nutrition. United Nations Sustainable Development Group. Available online at: https://unsdg.un.org/resources/poli cy-brief-impact-covid-19-foodsecurity-and-nutrition

Weersink, A., Massow, M. von, and McDougall, B. 2020. Economic thoughts on the potential implications of COVID-19 on the Canadian dairy and poultry sectors. Canadian Journal of Agricultural Economics, 68(2), 195-200. https://doi.org/10.1111/cjag.12240

WHO. 2020. Impact of COVID-19 on people's livelihoods, their health and our food systems. Available o $\mathrm{n} 1 \mathrm{i} \mathrm{ne}$ a t : https://www.who.int/news/item/13 -10-2020-impact-of-covid-19-onpeople's-livelihoods-their-healthand-our-food-systems

Yaffe-Bellany, D., and Corkery, M. 2020. Dumped Milk, Smashed Eggs, Plowed Vegetables: Food Waste of the Pandemic. The New York Times. Available online at: https://www.nytimes.com/2020/04 / 11 / business / coronavirus destroying-food.html

Yahaya, H., Yusuf, V. A., Giginyu, I. M., Adama, D. S., Ramoni, R., and Adibe, T. 2020. Nigeria: Alarm Bells As COVID-19 Cripples Poultry, Fish Farming Biz. Daily Trust web page. available online at: https://dailytrust.com/alarm-bellsas-covid-19-cripples-poultry-fishfarming-biz.

Received: $12^{\text {th }}$ October, 2020 Accepted: $5^{\text {th }}$ February, 2021 